\title{
Prognostiske biomarkører i lungekreft
}

\author{
Det metastaserelaterte proteinet osteopontin er lovende som prognos- \\ tisk biomarkør i ikke-småcellet lungekreft.
}

Hvorvidt pasienter med ikke-småcellet lungekreft som gjennomgår kirurgi blir behandlet med adjuvant kjemoterapi, avhenger av sykdomsstadium. Ikke-småcellet lungekreft er en av de mest heterogene krefttypene, med betydelig variasjon i tumorbiologi og prognose også for pasienter i samme stadium. Identifisering av prognostiske biomarkører kan gjøre det mulig å underklassifisere pasientene ytterligere på bakgrunn av prognose.

I mitt doktorarbeid har jeg undersøkt den kliniske betydningen av tre metastaserelaterte proteiner samt tilstedeværelsen av disseminerte tumorceller i beinmargen hos over 200 pasienter med ikke-småcellet lungekreft i tidlig stadium som gjennomgikk primæroperasjon. Vi fant at høyt uttrykk av proteinet osteopontin var assosiert med utvikling av metastaser eller tumorresidiv og var en uavhengig faktor for dårlig prognose. Siden en stor andel pasienter med ikke-småcellet lungekreft i tidlig stadium får tilbakefall av sykdommen på tross av operasjon, er det nærliggende å tro at systemisk disseminering av tumorceller foregår tidlig i sykdomsutviklingen. I vår studie fant vi imidlertid ingen prognostisk betydning av tilstedeværelsen av disseminerte tumorceller i beinmargen hos disse pasientene.

Ikke-småcellet lungekreft er den vanligste årsaken til kreftrelatert død i Norge. Økt molekylær forståelse kan føre til forbedringer innenfor diagnostikk og behandling av denne krefttypen. Osteopontin har potensial som prognostisk biomarkør for å selektere pasienter som kan ha nytte av adjuvant kjemopterapi.

\section{Ane Kristine Kongsgaard Rud}

anekkongsgaard@yahoo.com

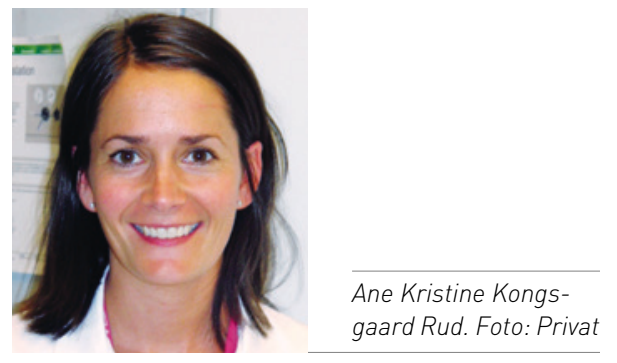

Disputas

Ane Kristine Kongsgaard Rud disputerte for ph.d.-graden ved Universitetet i Oslo 13.6. 2014. Tittelen på avhandlingen er Prognostic biomarkers and disseminated tumor cells in non-small cell lung cancer.

\section{Kardial dysfunksjon ved juvenil dermatomyositt}

\section{Ved den revmatiske systemsykdommen juvenil dermatomyositt kan affeksjon av hjertemuskelen være en langtidskomplikasjon. Mulige mekanismer kan være myokarditt eller aterosklerose.}

Juvenil dermatomyositt er en sjelden hudog muskelbetennelse som oppstår i barneog ungdomsår. Andre organer, som hjertet, kan rammes, men mekanismene for dette er ikke klarlagt. Det er kjent at annen revmatisk sykdom, for eksempel revmatoid artritt, er assosiert med økt kardiovaskulær risiko selv ved lave kolesterolverdier.

Mitt doktorarbeid er basert på en tverrsnittsundersøkelse av de fleste norske pasienter med juvenil dermatomyositt diagnostisert i perioden 1970-2006. Ved ekkokardiografi var det redusert systolisk og diastolisk kardial funksjon hos disse sammenliknet med aldersog kjønnsmatchede kontrollpersoner. Pasientene hadde også økt nivå av kjemokinene MCP-1 og eotaksin, men lavere kolesterolverdier enn kontrollpersonene. Høye nivåer av MCP-1 og eotaksin var assosisert med kardial dysfunksjon hos pasientene, mens assosiasjon mellom kardial dysfunksjon og kolesterolverdier i øvre normalområdet bare var til stede hos pasientene med aktiv juvenil dermatomyositt (52\%), ikke hos dem med inaktiv sykdom (48\%) eller hos kontrollpersonene.

Funnene kan tyde på at prematur hjertesykdom, som også er sett ved andre inflammatoriske tilstander, er en langtidseffekt av juvenil dermatomyositt. Risikoen ser ut til å være knyttet til økt inflammasjonsnivå og aktiv sykdom. Forhøyede nivåer av MCP-1 og eotaksin kan medføre eller være uttrykk for senket terskel for ugunstig effekt av kolesterol. Mulige mekanismer for dette kan være lavgradig myokarditt eller aterosklerose i små kar.

Thomas Schwartz

thomas.schwartz@medisin.uio.no

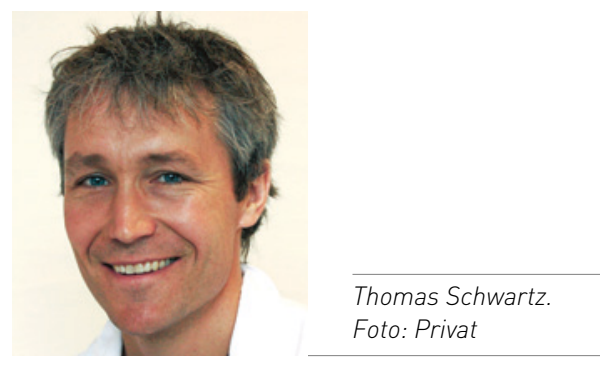

Disputas

Thomas Schwartz disputerte for ph.d.-graden ved Universitetet i Oslo 17.6. 2014. Tittelen på avhandlingen er Cardiac dysfunction and cytokine profile in juvenile dermatomyositis. 